\title{
Manufacturing of One-side Galvanized and Galvannealed Steel Sheet by Masking Coat ${ }^{*}$
}

\author{
By Shigeru KOBAYASHI,** Hideo KOUMURA,** Makoto HIMENO,** \\ Toshio IRIE, ${ }^{* *}$ Yoshinori FUJITA, ${ }^{* * *}$ Kuniaki SATO*** and Tadahiro YUSA ${ }^{* * *}$
}

\section{Synopsis}

A process for producing one-side galvannealed steel sheet by masking coat has been developed. The functions of masking coat consisting of sodium silicate, sodium borate, magnesia, titania and alumina are in masking and repelling from molten zinc and easily exfoliating by light bending after galvannealing heat treatment. The ungalvannealed side surface has an excellent cosmetic corrosion resistance due to fine phosphate coating originating from the very small quantity of zinc deposition of several $\mathrm{mg} / \mathrm{m}^{2}$. The galvannealed layer can be free from powdering by reducing the coating weight to as low as $20 \mathrm{~g} / \mathrm{m}^{2}$ on one side with the aid of flame wiping and air knife. Deep drawable steel sheet can be made in a continuous galvanizing line without pre- or post-annealing by adopting an extra low carbon steel stabilized with niobium. Thus produced galvannealed steel sheet is considered to be an excellent material against both perforation and cosmetic corrosion for car body exposed panels.

\section{Introduction}

It is well known that the lapped portions in the outer panels of automotive body such as a hood or door are the most susceptible to the perforation corrosion. Since the phosphate and electrodeposition coating hardly enter the interior of the lapped portions, these panels must be pre-coated for suppressing the perforation corrosion. On the other hand, the exposed side of these outer panels should be uncoated cold-rolled steel surface for the adhesion and appearance after painting. Therefore, the outer panels are mainly made of one-side pre-coated steel sheets.

Among the several kinds of one-side pre-coated steel sheets used for this purpose, hot-dipped one-side galvannealed ( $\mathrm{Zn}-\mathrm{Fe}$ alloy) is known to have excellent anti-perforation corrosion resistance, ${ }^{1)}$ spot weldability and paint adherence, while the powdering being the only defect.

However, one-side galvannealed by mechanically grinding has serious defects that the ground uncoated surface has slivers with remained zinc, and under paint film rust will occur along them. Moreover, the processing cost of grinding is much expensive.

A process for non-grinding one-side galvannealing by masking coat has been developed, ${ }^{2-4)}$ and the metallurgy of the process and properties of the product are given in this paper.

\section{Manufacturing Process}

The manufacturing apparatus is shown schematically in Fig. 1, which is composed of an electrodegreasing, a masking coat applicator in Fig. 2, a flame wiper $^{5)}$ in Fig. 3, and a masking coat remover ${ }^{6}$ in Fig. 4, installed in a usual CGL with in-line annealing furnace.

The water slurry for masking coat is applied to oneside of a degreased strip. After preliminary drying at $300{ }^{\circ} \mathrm{C}$ for $20 \mathrm{sec}$ in air, the resulting masking coat is fired in the annealing furnace consisting of non-oxidizing heating furnace and soaking furnace in reducing atmosphere of $15 \% \mathrm{H}_{2}-\mathrm{N}_{2}$. By this firing, a glassy film is formed. Since this glassy film has a good repelling property against molten zinc, adherence of zinc on it scarcely occurs in the following galvanizing process. However, dross or fine zinc particles may very rarely scattered on the surface. Therefore, the complete removal of these zinc residues is accomplished by wiping the glassy film with a flame wiper just above the zinc pot after galvanizing. After galvanizing followed by air wiping for controlling the amount of zinc on the galvanized surface in air atmosphere, the strip passes through the alloying heat treatment furnace. The glassy film keeps the ungalvanized surface from the oxidation by air. Continuously, the glassy film is completely exfoliated using a bending roll.

The one-side galvannealed steel strip thus obtained is finally temper rolled in line. The appearance of the ungalvannealed surface is quite the same as that of the ordinary cold-rolled steel strip. Also, the appearance of the galvannealed surface is the same as that of the ordinary two-side galvannealed steel strip since there is no essential difference in the both processes.

\section{Properties of Masking Coat}

\section{Composition}

The masking coat basically consists of water slurry containing sodium silicate, sodium borate and magnesium oxide. Titanium oxide and aluminum oxide are added to this basic composition. ${ }^{7,8)}$ The glassy film, that is, fired masking coat in the annealing furnace, has the following properties:

1) To protect the transmission of zinc and air through the glassy film in zinc pot and heat treatment for galvannealing

2) To repel the molten zinc on the masking film

3) To be exfoliated by light bending after galvannealing.

\section{Structure}

The influence of firing temperature on the covering

* Received March 29, 1983. (C) 1983 ISIJ

** Research Laboratories, Kawasaki Steel Corporation, Kawasaki-cho, Chiba 260.

*** Chiba Works, Kawasaki Steel Corporation, Kawasaki-cho, Chiba 260. 
process of the masking coat observed with SEM is shown in Photo. 1. Since the rearrangement and flowing of the glassy film is insufficient at $700{ }^{\circ} \mathrm{C}$ yet, there is some cracks on the film and the covering is incomplete. However, the covering is perfect over $800{ }^{\circ} \mathrm{C}$. The reflecting X-ray diffraction of the glassy film fired at $800^{\circ} \mathrm{C}$ is shown in Fig. 5. The diffraction pattern of sodium disilicate and magnesium oxide was measured but that of borate was not. The borate

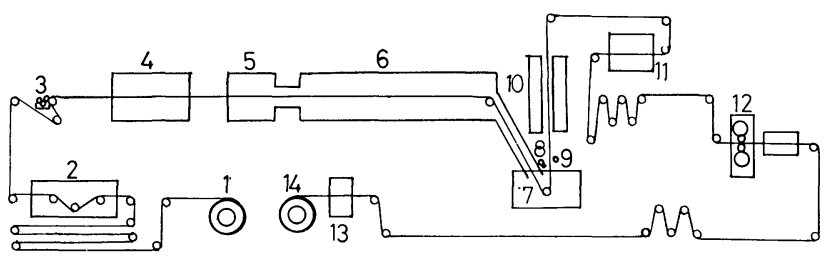

1 Uncoiler

2 Electrodegreasing tank

3 Roll coating unit

4 Preliminary drying furnace

5 Non-oxidizing furnace

6 Reducing furnace

7 Galvanizing bath

8 Flame wiping unit

9 Air knife

10 Galvannealing furnace

11 Removing unit

12 Temper roll

13 Oiler

14 Recoiler

Fig. 1. Profile of continuous galvanizing line for producing one-side galvannealed steel sheet.

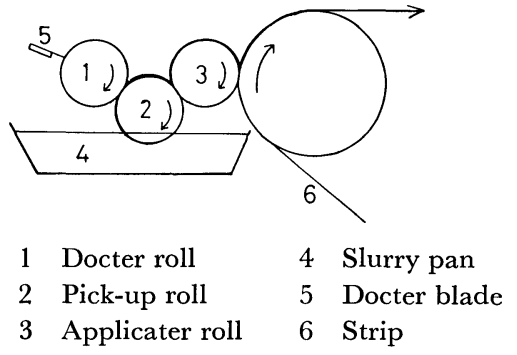

Fig. 2. Roll coater unit. seems to be amorphous in the film. The reflecting diffraction intensity of sodium disilicate, (203) plane, in the film with $20 \mu \mathrm{m}$ thickness was measured against temperature as shown in Fig. 6. The diffraction nitensity increases with temperature but decreases over $800^{\circ} \mathrm{G}$.

The crystallization of coated sodium silicate progresses until $800^{\circ} \mathrm{C}$ and the melting of that occurs at over $800^{\circ} \mathrm{C}$ followed by the glassification through cooling process.

\section{Zinc Repelling}

The masking coat on one-side of the strip is sunk into the molten zinc after annealing. When the molten zinc adheres on the surface of the glassy film, that

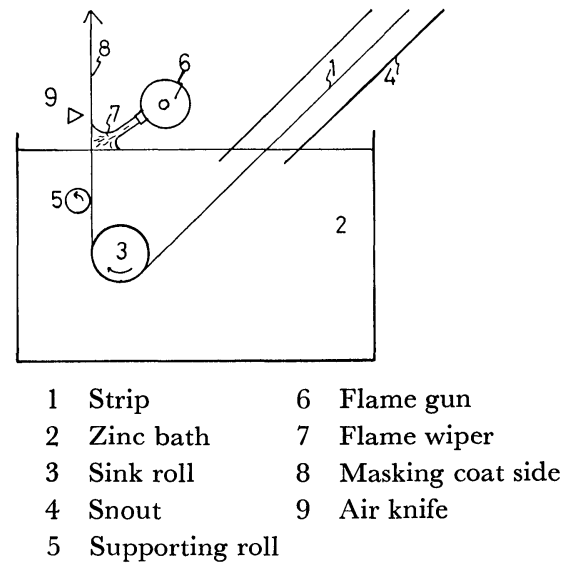

Fig. 3. Flame wiper unit above zinc bath.
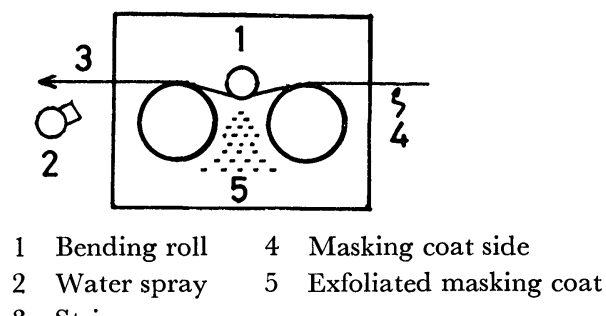

3 Strip

Fig. 4. Removing unit.

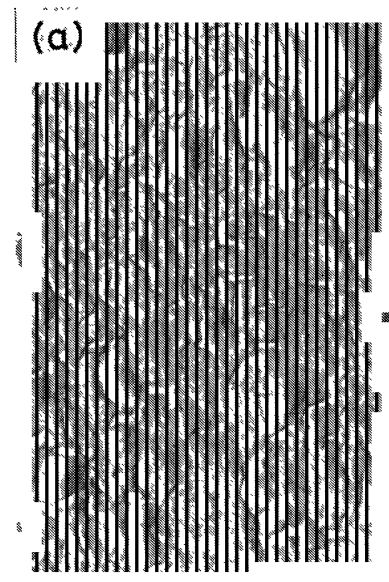

(a) $700^{\circ} \mathrm{C}$

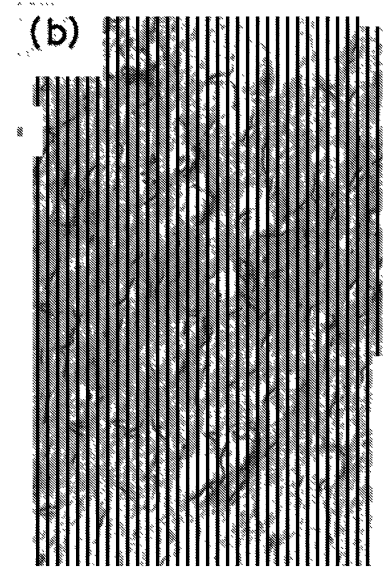

(b) $750^{\circ} \mathrm{C}$

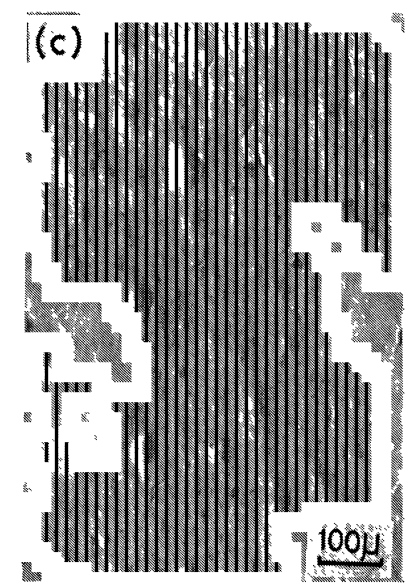

(c) $800^{\circ} \mathrm{C}$

Photo. 1. Scanning electron micrographs of basic masking coat at various annealing temperatures. 
is hardly exfoliated and wasteful. The previously mentioned masking coat with basic composition is easily wetted by molten zinc because its softening temperature is as low as the melting point of zinc.

The addition of the oxides with high melting point to basic masking coat composition has an effect to avoid the wetting by molten zinc on the fired glassy film.

The surface configuration on the glassy films added with titanium oxide and aluminium oxide at every annealing temperature is shown in Photo. 2. There are uneven needle crystals on the glassy films at between $800{ }^{\circ} \mathrm{C}$ and $900{ }^{\circ} \mathrm{C}$. These needle crystals are absorbed in the glassy film matrix over $900^{\circ} \mathrm{C}$. Since the adsorption of molten zinc on the glassy film occurs under $800{ }^{\circ} \mathrm{C}$ or over $900^{\circ} \mathrm{C}$, these needle crystals may suppress the wetting by molten zinc on the glassy film.

The X-ray diffraction of titanium oxide and its compound on the glassy film is observed at every annealing temperature as shown in Fig. 7. The titanium oxide changes into magnesium titanium oxide with increasing temperature. The needle crystals on the glassy film is mainly composed of titanium oxide. Consequently, this oxide plays a roll of repelling the molten zinc. Because the titanium oxide hardly resolves into glassy film between $800^{\circ} \mathrm{C}$ and $900^{\circ} \mathrm{C}$, this remains on the surface of the film and recrystallizes as the needle crystals. The aluminum oxide supports to delay the absorption of titanium oxide into glassy film, because unless alumina is added, titania is absorbed under $900^{\circ} \mathrm{C}$.

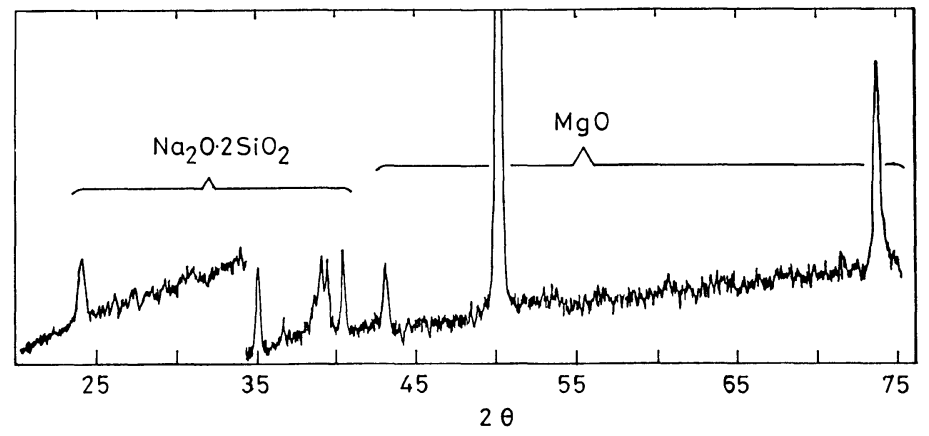

Fig. 5. X-ray diffraction pattern of masking coat annealed at $800^{\circ} \mathrm{C}$.

\section{Removing}

The glassy film is easily exfoliated by light bending, because glassy film is rigid and brittle like glass. The residue of the component in masking coat on the

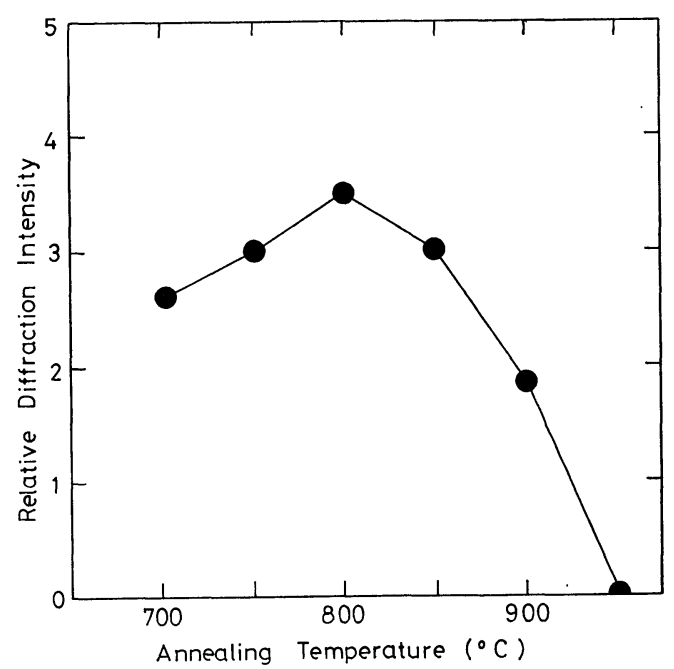

Fig. 6. X-ray diffraction intensity of $\mathrm{Na}_{2} \mathrm{O} \cdot 2 \mathrm{SiO}_{2}(203)$ in masking coat at various annealing temperatures.

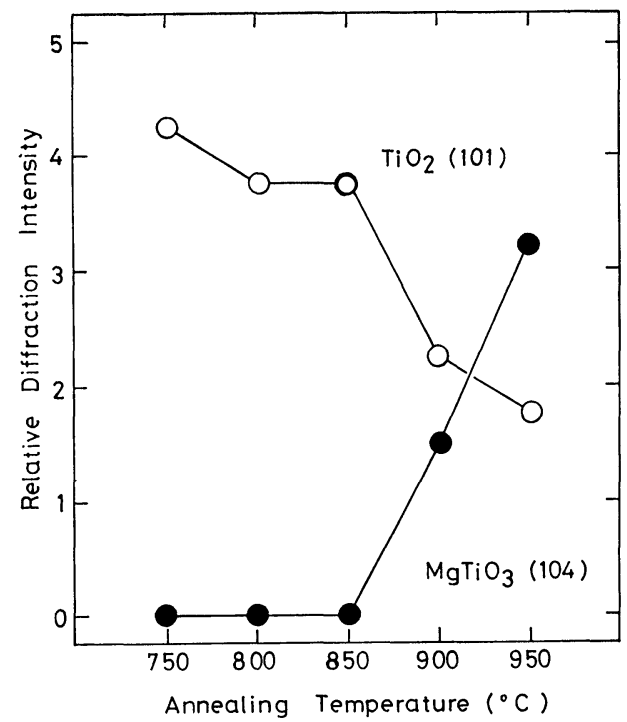

Fig. 7. X-ray diffraction intensity of $\mathrm{TiO}_{2}$ and $\mathrm{MgTiO}_{3}$ on masking coat at each annealing temperature.

(Coating thickness : $20 \mu \mathrm{m}$ )

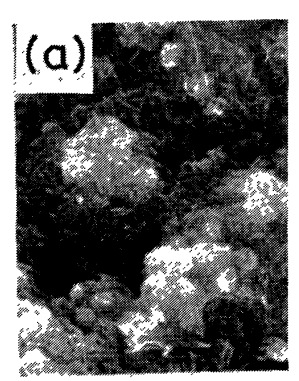

(a) $750^{\circ} \mathrm{C}$

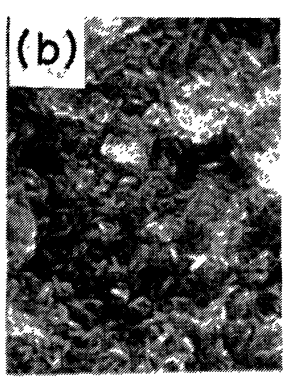

(b) $800^{\circ} \mathrm{G}$

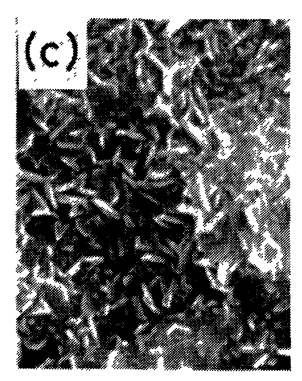

(c) $850^{\circ} \mathrm{G}$

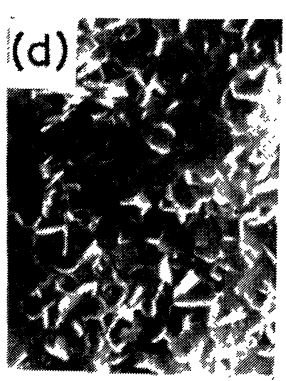

(d) $900^{\circ} \mathrm{C}$

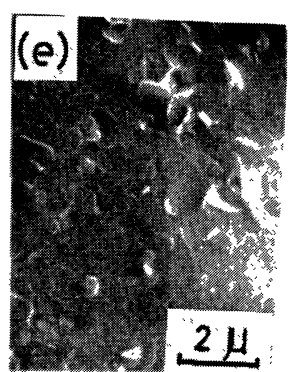

(e) $950^{\circ} \mathrm{G}$

Photo. 2. Scanning electron micrographs of masking coat contained $\mathrm{TiO}_{2}$ and $\mathrm{Al}_{2} \mathrm{O}_{3}$ at various annealing temperatures. 
ungalvannealed surface after removing the glassy film is under $20 \mathrm{mg} / \mathrm{m}^{2}$. The transmission of zinc through the glassy film is several $\mathrm{mg} / \mathrm{m}^{2}$.

\section{Properties of Ungalvannealed Surface}

\section{Phosphatability}

The zinc residue on the ungalvannealed side has been found to be very important for the phosphatability. The relation between the zinc residue on the ungalvannealed surface and the size of phosphate crystals is shown in Fig. 8. Moreover, the crystal configurations of some samples observed with SEM is shown in Photo. 3. A lot of zinc residue over 45 $\mathrm{mg} / \mathrm{m}^{2}$ introduced by the transmission through masking coat causes the phosphate crystals to become rough and sparse because the hopeite $\left(\mathrm{Zn}_{3}\left(\mathrm{PO}_{4}\right)_{2}\right)$ formed on zinc layer easily resolves in phosphate treatment liquid itself and few nuclei grow up into large crystals.

When the zinc residue on the surface of the ungalvannealed side is several $\mathrm{mg} / \mathrm{m}^{2}$, the configuration of phosphate crystals is better than even the zinc free surface such as ordinary cold-rolled steel sheet. The very small quantity of zinc residue on the ungalvannealed side is considered to act as reaction nuclei at phosphate crystals formation.

\section{Corrosion Resistance after Painting}

The corrosion resistance of the ungalvannealed side painted with three layered coats for automotive use was tested with $440 \mathrm{hr}$ salt spraying. The results are

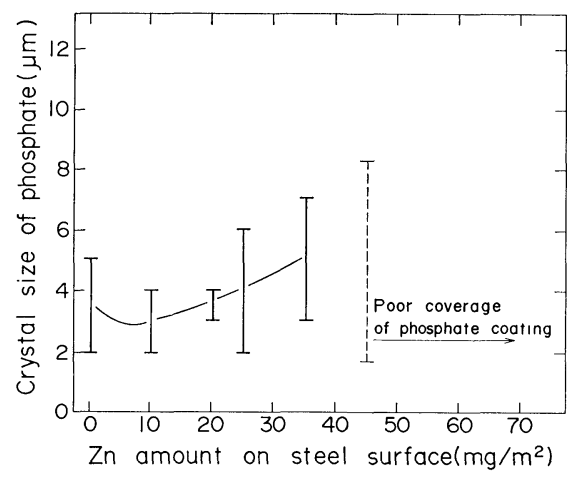

Fig. 8. Relation between zinc residue on the steel surface and crystal size phosphated by Bonderite 3004, dipping type. shown in Photo. 4. Red rust at the cross scribe in the ungalvannealed side hardly occurs as compared with usual cold-rolled steel sheet, and the reason is referred to that it has excellent phosphate due to deposition of several $\mathrm{mg} / \mathrm{m}^{2}$ zinc.

\section{Properties of Galvannealed Surface}

\section{Extra Light Weight Galvannealing}

Generally, a lighter weight galvanizing under 45 $\mathrm{g} / \mathrm{m}^{2}$ per one side is difficult to be manufactured in conventional hot dipped galvanizing process.

However, an extra light weighed coat such as 20 $\mathrm{g} / \mathrm{m}^{2}$ per one side can be produced in this process by

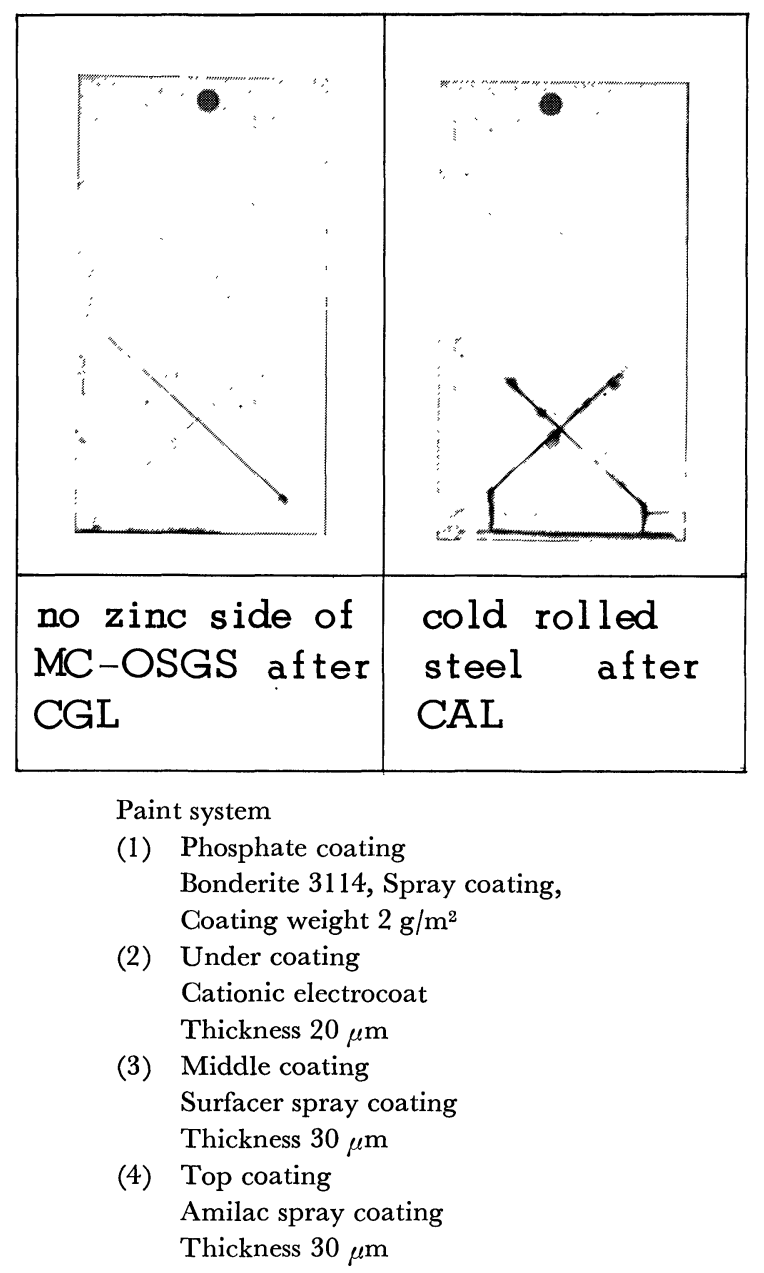

Photo. 4. Appearance of painted specimens after SST (440 hr).

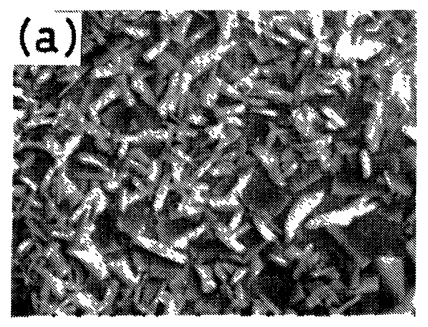

(a) $45 \mathrm{mg} / \mathrm{m}^{2}$

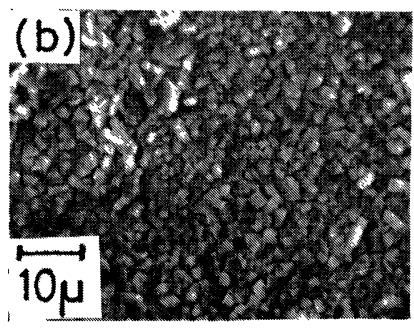

(b) $7 \mathrm{mg} / \mathrm{m}^{2}$

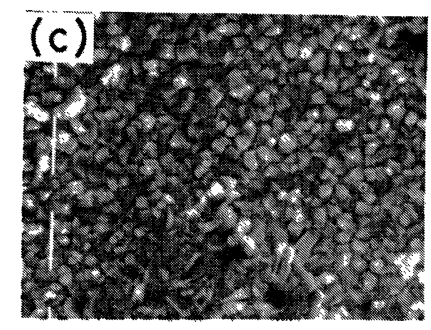

(c) zero (cold-rolled steel)

Photo. 3. Configuration of phosphate crystals to each remained zinc observed with SEM. (phosphate treatment: Bonderite 3004) 
masking coat. The reason is considered in the following; because the previously mentioned flame wiper heats the glassy film and enhances the fluidity of molten zinc on the opposite side of the strip, zinc layer was easily wiped by the air knife.

The surface configuration and roughness of the extra light weight coated galvannealed layer are shown in Photo. 5 and Fig. 9 as compared with conventional weight coated ones. The extra light weighed coat has finer crystal size and smoother surface than the conventional one. The reason is referred to the more nucleation of $\mathrm{Zn}-\mathrm{Fe}$ alloying and faster diffusion of iron into zinc layer due to faster heat conduction through the thinner zinc layer.

\section{Spot-weldability}

The spot weldability of the extra light weight coated galvannealed steel sheet was compared with a conventional one. The profile of electrode and the assembly for a pair of sheets are shown in Fig. 10. The relation between welding current and button diameter is shown in Fig. 11. Since the proper current of weld-

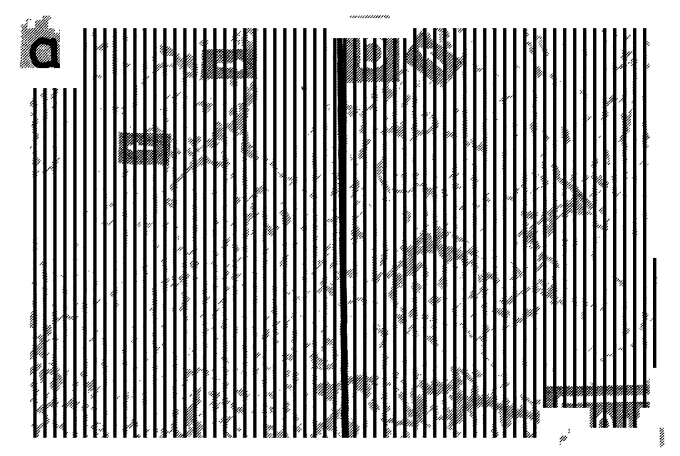

$\rightarrow$ : Temper roll touched parts
(a) $20 \mathrm{~g} / \mathrm{m}^{2}$
(b) $45 \mathrm{~g} / \mathrm{m}^{2}$

Photo. 5. Surface configuration of galvannealed steel sheet observed with SEM.

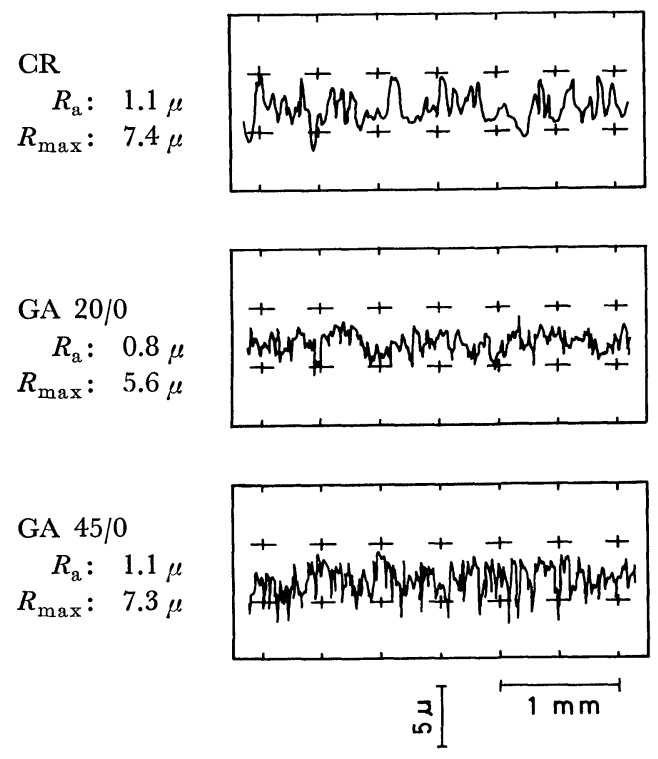

Fig. 9. Surface roughness of galvannealed and cold-rolled steel sheet. ing is clearly wider in the extra light weight coated one, the workability of welding will be improved in practical operation.

When the welding was examined at the condition of conventional weight coated one side galvannealed steel sheets with $9.5 \mathrm{kA}$, the tensile shear strength (400 $\mathrm{kgf})$ and the button diameter $(5 \mathrm{~mm})$ of the extra light weight coated one was the same as the initial one after 6000 spots.

\section{Powdering}

The only fault of conventional galvannealed steel sheet has been powdering at press forming.

The powdering property with three kinds of coating weight was examined with the $0 \mathrm{~T}$ bending and Du Pont impact test by dropping $1 \mathrm{~kg}$ weight from 50 $\mathrm{cm}$ height on a sphere of $1 / 2$ inch diameter set on the sample. The appearance after these two tests and the amount of powdered-off show in Photo. 6 and Fig. 12, respectively. The powdering decreases with decreasing coating weight. There is few powdering in the developed extra light weight coated one.

This excellent property may be caused not only by light weight but also by fine crystal size of $\mathrm{Zn}-\mathrm{Fe}$ alloy.

\section{Mechanical Properties}

Recently developed extra low carbon steel containing niobium ${ }^{9)}$ can accomplish extra deep drawability and non aging quality by hot-dipped galvannealing in GGL without any pre- or post-annealing. The chemical compositions and mechanical properties

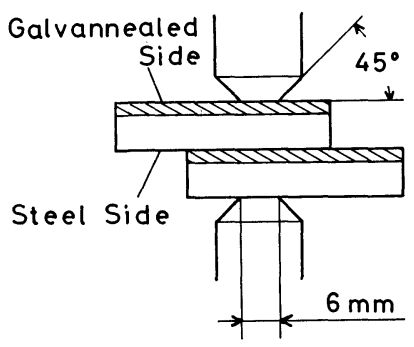

Fig. 10. Profile of spot welding electrodes and assembly for a pair of sheets.

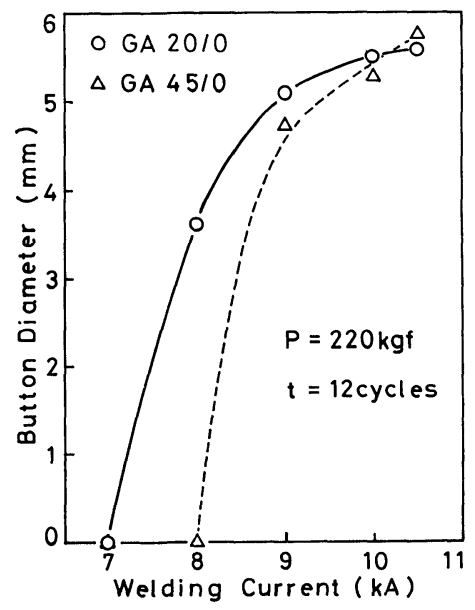

Fig. 11. Button diameter after spot welding. 
after galvannealing of this steel sheet are shown in Table 1.

An example of press formed picture of an automotive wheel house is shown in Photo. 7.

\section{Conclusions}

A deep drawable and non aging hot-dipped oneside galvannealed steel sheet to be an excellent material for automotive outer panel use was developed by

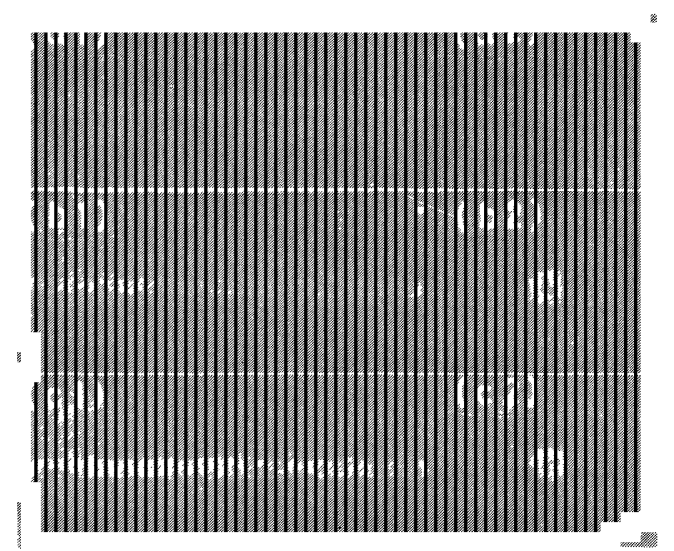
(a) $20 \mathrm{~g} / \mathrm{m}^{2}$
(b) $45 \mathrm{~g} / \mathrm{m}^{2}$
(c) $60 \mathrm{~g} / \mathrm{m}^{2}$

Photo. 6. Appearance of powdering on cellophane tape after 0T bending (a1), (b1), (c1) and Du Pont impact (a2), (b2), (c2).

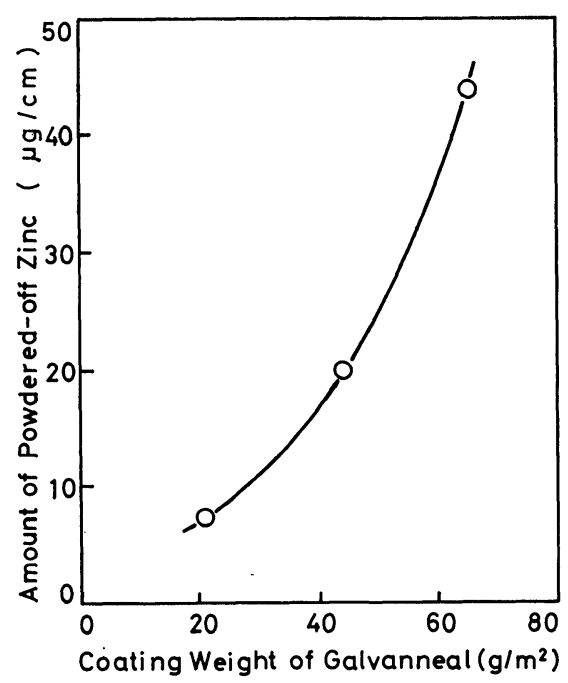

Fig. 12. Relation between amount of powdered-off and coating weight after OT bending. masking coating method. The results were reached in the following:

(1) The hot-dipped one-side galvannealed steel strip can be manufactured in a conventional continuous galvanizing line of the in-line anneal type in which an electrodegreasing, masking coat applicating, preliminary drying, flame wiping, galvannealing heating and masking coat exfoliating installation are added.

(2) The masking coating material composed of sodium silicate, sodium borate, magnesia, titania and alumina has the characteristics such as a protecting the transmitting of molten zinc and air onto steel strip surface, repelling from molten zinc and exfoliating of itself by light bending after galvannealing.

(3) The ungalvannealed surface after exfoliating of masking coat has excellent phosphatability due to an optimum residue of several miligram per square meter of zinc.

(4) The galvannealing layer with an extra light weight as low as $20 \mathrm{~g} / \mathrm{m}^{2}$ on one side can be obtained in this process. Therefore this one can be free from powdering on bending and impact test due to an extra light weight and fine crystals of zinc iron alloy and will be welded with lower current than conventional one.

(5) The deep drawable and non aging galvannealed steel sheet can be made using the material with extra low carbon containing niobium without pre- or post-annealing.

\section{Acknowledgements}

The authors would like to thank Mr. T. Shimizu of Chiba Works in Kawasaki Steel Corporation, Mr. F.

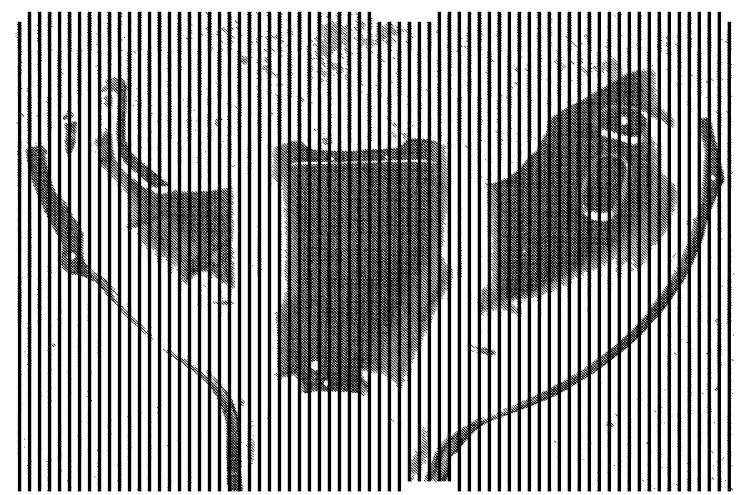

Photo. 7. Appearance after press of one-side galvannealed steel sheet.

Table 1. Chemical compositions of KTUX and mechanical properties after one-side galvannealing.

\begin{tabular}{|c|c|c|c|c|c|c|c|c|c|c|c|c|c|c|}
\hline \multirow[b]{3}{*}{ KTUX*1 } & \multicolumn{7}{|c|}{$\begin{array}{l}\text { Chemical compositions } \\
\text { (wt } \%)\end{array}$} & \multicolumn{6}{|c|}{$\begin{array}{l}\text { Mechanical properties after } \\
\text { one-side gralvannealing }\end{array}$} & \multirow{2}{*}{$\begin{array}{l}\text { thickness } \\
(\mathrm{mm})\end{array}$} \\
\hline & G & $\mathrm{Si}$ & $\mathrm{Mn}$ & $\mathrm{P}$ & $\mathrm{S}$ & $\mathrm{Al}$ & $\mathrm{Nb}$ & $\underset{(\mathrm{kgf} / \mathrm{mm}}{\mathrm{YS}}$ & $\begin{array}{l}\text { TS } \\
\left.a^{2}\right)\end{array}$ & $\begin{array}{c}\mathrm{E} 1 \\
(\%)\end{array}$ & $\begin{array}{c}\mathrm{YE} 1 * 2 \\
(\%)\end{array}$ & $\bar{r}$ & $A I^{* 3}$ & \\
\hline & 0.002 & 0.020 & 0.15 & 0.013 & 0.008 & 0.04 & 0.015 & 19 & 31 & 49 & 0 & 2.0 & $0 \sim 0.1$ & 0.8 \\
\hline
\end{tabular}

*1 Extra deep drawable steel sheet with extra low carbon containing niobium

*2 Yield point elongation

*3 Aging index $\left(100^{\circ} \mathrm{G} \times 30 \mathrm{~min}\right.$ after $7.5 \%$ prestrain $)$ 
Ishizaki of Kawasaki Steel America Inc. and Mr. T. Michigami of Chiba Works in Kawatetsu Galvanizing Corporation for their assistance in the successful completion of the process.

\section{REFERENCES}

1) S. Kobayashi, T. Irie and H. Takahashi: SAE Tech. Paper No. 830492, (1983).

2) M. Gotou, H. Koumura, Y. Fujita and S. Harada: Tetsuto-Hagané, 66 (1980), 852.
3) M. Gotou, S. Harada and N. Ohashi: SAE Tech. Paper No. 810142, (1981).

4) S. Shijima, S. Harada, M. Gotou, F. Ishizaki and T. Shimizu: Tetsu-to-Hagané, 68 (1982), A45.

5) Publication of Japan Patent No. 28744-1982.

6) Laying Open of Japan Patent No. 52465-1983.

7) Laying Open of Japan Patent No. 174439-1982.

8) S. Kobayashi, H. Koumura, K. Kyono, M. Gotou and T. Irie: J. Metal Finishing Japan, 33 (1982), 497.

9) O. Hashimoto, S. Sato and T. Tanaka: Tetsu-to-Hagané, 67 (1981), 1962. 